\title{
The Potential Impact of AEC 2015 on the Small Farmers of Myanmar
}

\author{
Lalrin Chhani \\ Graduate School, MBA, Stamford International University, Bangkok 10250, THAILAND \\ *E-mail for correspondence: deborahlrch@gmail.com
}

Received: Apr 28, 2016

Accepted: May 15, 2016

\begin{abstract}
The aim of this study is to find out the potential impact of AEC by comparing the farmers' and the government officials' perspective, and then find a solution for the farmers' problem by using AEC. The research was done by discussing with six farmers' family and three government officials. The participating farmers were chosen with the help of the government officials. The participants of the government can be divided into two, the one who had direct contact with the farmers and the one who formulate agriculture plans and development of agriculture sector.

The significant research findings were the following: 1) Problems and challenges of the farmers in the current situation; 2) How did the farmers perceived and understand the AEC?; 3) What were the farmers' expectations and how did they prepare for the AEC?; 4) How did the government perceive the AEC?; 5) What will the potential impact of the AEC be for the small land farmers in Myanmar?; and 6) What should the farmers do in order to solve their problems and make wise use of the AEC?
\end{abstract}

Keywords: Small Farmers, problem solving, potential impact of AEC

\section{INTRODUCTION}

The ASEAN Economic Community (AEC) is the realization of the end goal of economic integration in the Association of South East Asian Nations (ASEAN). One of the characteristics of AEC is to create a stable, prosperous and highly competitive economic region in which there is a free flow of goods, service and investments, a freer flow of capital (http://www.asean.org/asean/about-asean/overview/).

The actualization of AEC will bring many opportunities and challenges for the member countries. Thus, as one of the member countries, Myanmar will also gain advantages from many different aspects.

Agriculture has always been the main industry in Myanmar economy. It covers around 34\% of the GDP (Myanmar Agriculture in Brief, 2011) and 65.6\% of the labor force (ADB, 2014). Farmers, who played the most important role in agriculture, were the backbone of Myanmar's economy throughout the history. At present, even though the agriculture still remains as the primary sector of the economy, it is declining and the farmers' community became weak and lacking productivity. It is important for the farmers to be strong and productive in order regenerate the agriculture sector. Therefore, this paper will find out the farmers' problem and solution for them by using AEC as a problem solving tools.

\section{LITERATURE REVIEW}

The potential impact of AEC 2015 on small farmers of Myanmar can be predicted through the studies of AEC, the opportunities and challenges it would bring, and the studies of the impact of Economic Integration upon some other countries in and outside the ASEAN region.

$\mathrm{AEC}$, as stated in the blueprint, is the realization of the end goal of economic integration of ASEAN countries. The vision of ASEAN 2020 declared in 2003 was to establish ASEAN community comprised of ASEAN economic community (AEC), ASEAN political -Security Community (ASC) and ASEAN Socio Cultural Community (ACC). ASEAN regional economic integration will happen in 2015 and the complete economic integration is planned for 2020. The main aim of AEC is to create a stable, highly competitive and prosperous ASEAN Economic Region which will result in an equitable economic development and reduction of poverty and sell socio-economic disparities.

The main characteristics of AE Care: a single market and production base, a highly competitive economic region, a region of equitable economic development, and a region fully integrated into the global economy (ASEAN, 2008). A single market and production base shall be comprised of five core elements: free flow of goods, free flow of services, free flow of investment, free flow of capital, and 
free flow of skilled labor. A highly competitive economic region shall be comprised with competition policy, consumer protection, intellectual property rights, and infrastructure development. Equitable economic development shall be comprised of small and mediumsize enterprises and initiative for ASEAN integration. A region fully integrated into the global economy shall be comprised of a coherent approach towards external economic relations and enhanced participation in global supply networks (ASEAN, 2008).

In order to implement the programs and measures of AEC, ASEAN has formed several ministerial and sectorial bodies' so-called implementation mechanism to coordinate with government agencies responsible for overseeing the implementation and preparation of more detailed action plans at the national level. Resources and capacity building supports from various facilities such as The ASEAN Development Fund, World Bank, and the IFC (International Finance Corporation) and others are mobilized. Good communication systems for the stakeholders, including the business communities are being promoted and periodical revision and progressive accounts of the implementation process will be undertaken.

ASEAN Ministers on Agriculture and Forestry (AMAF) is mainly designed for the sectors of agriculture, food and forestry to enhance food security, food handling, crops, livestock, fisheries, agricultural training and extension, agricultural cooperatives, forestry and joint cooperation in agriculture and forest products promotion scheme (asean.org). The three basic objectives of the ASEAN cooperation in food, agriculture and forestry are: 1) to formulate and implement regional cooperation activities; 2) to enhance the international competitiveness of ASEAN's food, agriculture and forestry products; and 3) to strengthen the food security in the region (http://www.asean.org/asean-economic-community/ asean-ministerial-meeting-on-agriculture-and-forestry-amaf/).

SOM-AMAF (Senior Office Meeting of AMAF) is the main ASEAN body that oversees the overall ASEAN cooperation in food and agriculture under the guidance of AMAF. It is formed to respond to the modern globalization of trade by enhancing food, agricultural and forestry products competitiveness in international markets while sustaining agricultural production. The main function of SOM-AMAF is to set the standard of agriculture products, by using Good Agricultural Practice (GAP).

ASEAN GAP is a regional standard to prevent the risks associated with production, harvesting and post-harvest handling of fresh fruits and vegetables and to facilitate their trade within and beyond the region. It sets the standard practice of on-farm production activities as well as that of local industries where the products are processed and packed for sale. It is designed in four separate modules: food safety; environmental management; workers' health, safety and welfare; and produce quality to ensure that the associated risk factors are properly addressed and the content integrations across the modules are maximized (The ASEAN Secretariat, 2006).

\section{The study of the possible impact of AEC through literature}

As mentioned before, AEC is the end goal of economic integration within ASEAN the countries. Thus, by looking through the impact of economic integration in other countries and regions, the impact of AEC can be predicted.

The impact of AFTA on Vietnam economy: The study of the impact of AFTA on Vietnam shows that the tariff reduction has boosted the competitiveness in local products and that free trade has created a larger market and encouraged more production and exports. It also attracted more foreign investment, as it lowered the taxation of investment and yielded lower prices which led to high demand and volume imports. The free flows of capital, labor and technology accelerated the transformation of production structure and the production increased. But it also ruined poorly competitive products. The products of Vietnam were lower value added products compared to foreign products and could not compete with those from foreign enterprises. Moreover, the human resources in Vietnam were still limited. It was important to be well preparing in terms of language, professional skills and working methods in order to effectively benefit from the AFTA (Thanh Loc, V.T., 2001).

The impact of AFTA on Philippines Economy and small scale producers: The tariff reduction attracted more foreign and domestic investment, skills and modern technology. The government of the Philippines has raised a public awareness and conducted skilled service training in order to solve the low productivity which was caused by insufficient and inefficient post-production facilities.

The impact of AFTA on Indonesian economy and small scale producers: Indonesia had a high intra-ASEAN export and a positive trade balance. The tariff reduction also attracted many foreign and domestic investors. The flow of capital, labor and technology helped to speed up the transformation of production structure and capacity. The implementation of AFTA had a positive impact on the economy of Indonesia as a whole but the small scale producers (farmers) had to face a lot of difficulties. The farmers suffered from high production expenses or high input costs, and their products did not meet the standard and could not compete in the global market. Moreover, the productivity also decreased due to the lower export earnings of the agriculture sector. Low selling prices of agriculture products and the transformation of subsistence production to commercial production caused the farmers to become increasingly poor. This caused the conversion of agricultural farms into housing and industrial areas, which led to an increased landlessness and decreasing farms sizes (Hidayat \& Regalado, 2006). 
Regional Free Trade Agreement in Southern Africa: It had a positive impact on the overall agriculture of Southern Africa. It brought two-fold benefits; gains for importers as a result of reduced industry protection; gains for exporters to markets with reduced protection. But the elimination of tariff between the Southern Africa Development Community (SADC) will reduce protection for low-income countries. Most of the economics of SADC are based on agriculture. So, trade in agricultural products could be helpful for fighting poverty, promoting integration and increasing economic growth and welfare (Nin-Pratt, Diao \& Bahta, 2008).

Impact of the US-Colombia FTA on the small farm Economy in Colombia: The study of the impact of USColombia FTA on the small farm economy in Colombia shows that there was a decreasing income and profits. The agricultural products of Colombia could not compete with those from the US in both, the international and domestic market. The short-cycle crops which were significantly exported by the US were mostly affected. The tariff reduction of these products resulted in a decreased income for the Colombian farmers. But because of the tariff elimination, the exchange rate and domestic price fell and the production costs for the farmers also decreased (Garay Salamanga, Gomez, \& Landinez, 2009).

\section{Methodology}

A qualitative data analysis was used to get insight information and a comparative analysis was used to make the information more reliable. Instead of using personal interviews, a group discussion was used to get the in-depth information. The research was conducted through five stages, 1) find the problems of the farmers, 2) find the farmers' perspective and expectations of AEC, 3) find out the opinion of the government officials, 4) evaluate and compare the two prospects, and 5) conclude and give further suggestions. The participants were six farmers' family and three government officials. The discussion with the farmers was held in three different villages. The participating farmers were chosen with the help of the local agricultural government officials. The interviewee from the government officials can be divided into two groups, one group is from the local agricultural office that has a direct contact with the farmers and the other from the Department of Agriculture Planning, who has a direct impact on the agriculture sector as a whole. The list of the participant can be seen in Table 1.

Table 1: List of Interview Participants

\begin{tabular}{|c|c|c|c|c|}
\hline Group & Participant's name & Village & Designation & Land owners (by acre) \\
\hline \multirow[t]{3}{*}{ Group 1} & U Tint Naing and family & Shwe Mya Yar & Farmers & 30 \\
\hline & U Ye MyintOo and family & Shwe Mya Yar & Farmer & 200 \\
\hline & U HlaThaung and family & Shwe Mya Yar & Farmer & 300 \\
\hline \multirow[t]{2}{*}{ Group 2} & U MyintOo and family & YoeWa & Farmers & 10 \\
\hline & U Moe Swe and family & YoeWa & Farmer & 16 \\
\hline Group 3 & Ko Aye Zaw and family & Myaung Taka & Farmers & 12 \\
\hline Discussion 1 & Dr. Thanda Kyi & Nay PyiDaw & $\begin{array}{l}\text { Director of the Department of } \\
\text { Agriculture Planning }\end{array}$ & - \\
\hline \multirow[t]{2}{*}{ Discussion 2} & Daw Hla Hla Myat & Yangon, Hmawbi & $\begin{array}{l}\text { Staff Officer of Hmawbi } \\
\text { Agricultural Department }\end{array}$ & - \\
\hline & U Thein Mint & Yangon, Hmawbi & $\begin{array}{l}\text { Staff Officer of Hmawbi } \\
\text { Agricultural Department }\end{array}$ & - \\
\hline
\end{tabular}

The discussion was guided by using the discussion topic instead of using an interview questionnaire so that the participants could freely discuss their opinion. The discussion questions were developed with the help of local government officials, who are experts in agriculture based on the aims of the research. 1) What are the problems and challenges the farmers face in the current situation?; 2) Do they know about the AEC, and how do they perceive and understand the AEC?: 3) What do they expect to gain from the AEC and what would be their preparation for the upcoming AEC? The topics for the discussion with the government officials were based on: 1) What do they think about the AEC, and how do they perceive it?; 2) Will the AEC be helpful to solve the problems of the farmers, and will it be beneficial for all the farmers?; and 3) How should the farmers prepare for the upcoming AEC to make a wide and advantageous use of it?

\section{RESULTS AND DISCUSSION}

According to the discussion with the farmers, there are presently four main challenges for the farmers, namely: limited irrigation, insufficient laborers, lack of a sustainable market and limitation of technology.

Irrigation: Irrigation is the life force of agriculture. Depending on the irrigation system, the farming is either successful or fails. Myanmar's agriculture system depends mainly on the monsoon weather. Thus, the farmers need to take a high risk to do farming. When there is too much or too less rainfall, the farmers are in troubles. They need a good draining system to protect from high rainfall and a good water supply for insufficient rainfalls as they need to pump the water with diesel-engine pumps and causes more input costs.

Laborers: The problem of insufficient laborers is another very important matter for the farmers. According to the farmers, almost all farmers have suffered from the 
insufficient supply of laborers. The reason is that due to the imbalance in income and expenses, the laborers leave the rural areas and go to the cities or to foreign countries to work in the factories, or as household helpers. This has a direct impact on the different stages of farming. The insufficient number of workers causes delay inploughing the fields and planting seeds, which in turn affects the productivity of crops. They cannot finish their work before harvest time, which result in unnecessary waste (Htoo Thit, 2013. P. 153).

Market: The agriculture market in Myanmar is under the control of secondary merchants, the "dealer". Most of the farmers (traditionally) are poor and have to take short-term loans to start farming. The loan must be settled after six months, i.e. at harvesting time. Thus, almost all farmers have to sell their crops to settle their loan. The price drops due to the increasing supply. There is not enough demand to sell the crops and the dealers have to store the excess crops. Additionally, dealer use manipulated scales to calculate the storage fees which results in a double loss for the farmers.

Limited Technology: Technology is a very important resource in agriculture. According to Win Shwe, 2013, technology is the only resource which can be controlled and improve by men, as natural resource cannot be controlled and labor resources are decreasing. Technology can be divided into two groups: technical technology and mechanization technology. According to the interviewees, they could get adequate advice about technical technology from the local agriculture department but have limited access to mechanical technology. Mechanization could be of help to the farmers in the process of land preparation, harvesting and threshing as there are insufficient laborers.

The possible impact of AEC, 2015, on the small farmers: Insights from the discussion

The farmers believed that the actualization of AEC would have a favorable impact pm them while the government officials thought that it will have both, positive and negative impacts. But both, the farmers and the officials agree that AEC will have more impact on the market and technology compared to other areas. The farmers hope that through AEC they will get in equal share with others and not be disadvantaged by the dealers as before.

According to the discussion with both the farmers and the government officials, the agricultural market will experience a significant change when the AEC is actualized. From the farmers' opinion, at the current situation, the market is under the control of the dealers and the market price is manipulated only by them. But when AEC is actualized, there will be a much wider market and the dealers cannot control it by themselves anymore. So, the farmers believe that they will be able to sell their products with a better price. Moreover, the market will be expended, and there will be more chances for them to sell their products. Therefore, the farmers are expecting to have an increased income.

As mentioned before, the government representatives believe that it will have both positive and negative impact on the farmers. When AEC is actualized, indeed the market will be expended and there will be more chances for the farmers to sell their products. But at the same time there will be a lot of competitions, so the farmers can sell their products only when they produce quality crops. If they cannot meet the ASEAN Good Agriculture Practice (GAP) standard and produce a quality product, it will be difficult for the farmers to sell their crops. It might turn out to be a disadvantage for the farmers.

For Technology, both the farmers and the government officials are expecting to gain benefits from AEC. Myanmar's agriculture technology, especially machinery, is laid back compared to other countries. So, they believe that when AEC comes, there will be more machinery import from other countries and the price will be cheaper because of the tariff reduction. Furthermore, because of the free flow of skilled labor, they are expecting to have a technology exchange with other ASEAN countries.

In addition to market and technology, Dr. Thanda Kyi, Director of Department of Agriculture Planning, mentioned investment. Insufficient funding is the most important problem at present. To have an overall development in agriculture, a lot of investment is required. With the necessary amount of investment, irrigation canals could be fixed; technology could be developed and could replace the lack of laborers. The development of irrigation and technology will lead to better quality crops. The quality crops could bring a promise for a good and sustainable market presented in Graph 1. Therefore, when AEC will bring the free flow of investment, it could also become a huge advantage for the farmers.

Graph 1: The step by step impact of Investment in agriculture

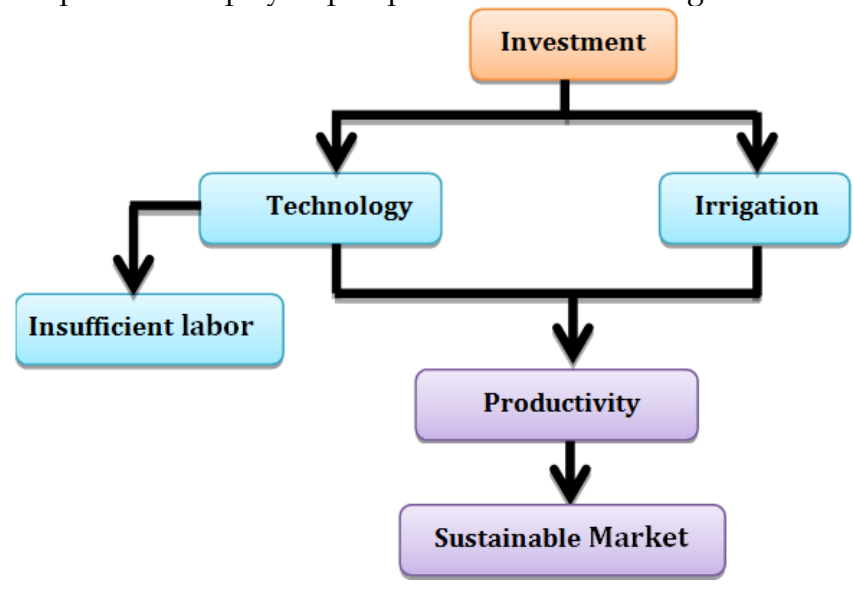

Sustainable Market 


\section{The possible impact of AEC 2015 in Myanmar}

The researcher has stated mainly what the farmers and the government officials expect from the actualization of AEC. In this section, the researcher states the overall possible impact of AEC on Myanmar through the interviews and the literature.

Economic growth: The economic growth of ASEAN Member States (AMS), which have been fully cooperating in building AEC, showed remarkable changes. The economic growth of AMS between 1989 and 2009 was, $6.73 \%$ for Singapore, $6.15 \%$ for Malaysia, $5.16 \%$ for Indonesia, $5.02 \%$ for Thailand, and 3.70\% for Philippines. It is to be expected that more economic growth will occur when AEC is actualized. As one of the ASEAN member who will participate in AEC, Myanmar will also experience economic growth.

A wider and sustainable market: As AEC will implement a single market policy within the ASEAN countries, the market will be expended from one country to ten countries. Furthermore, there will be free flow of capital and goods as the tariff will be reduced to $0 \%$. It will bring lower input cost for the farmers. But the single market will also raise a lot of competition within the markets. It is necessary to have a high quality product with low price to draw the customer's attention. This highly competitive market will become a huge challenge for the farmers, especially for the farmers in Myanmar. Depending on whether they can produce quality crops or not, they could gain or lose from the actualization of AEC.

Technological development: As mentioned above, the free flow of skilled labor will bring along the technology exchange within the community and the free flow of goods will make it easy to import machinery technology. Through these advantages, it will be easier for the farmers to practice GAP and Organic farming.

Infrastructure Development: In order to increase the practice of multi-cropping and improve access to both the domestic and international markets, infrastructure and irrigation have to be improved (Rasiah, Al-Amin \& Naing, 2011).Therefore, the ASEAN Transport Acton Plan (ATAP) has been carrying on certain transport actions, such as the ASEAN Highway Network (AHN), the Singapore-Kunming Rail Link (SKRL), and others. The infrastructure will be improved not only internationally, but also domestically to get ready for the distribution of goods, to implement mechanization farming etc (Umezaki, S., 2012).

Free flow of Investment: As mentioned before, investment could help the agriculture sector of Myanmar to recover (Appendix II) and help the development of the whole economy. Therefore, when AEC is established and the free flow of investment is being realizes, the farmers will have benefits in many different areas.
Decreasing laborers in agriculture sector: The establishment of AEC will bring more job opportunities in sectors than agriculture. So, it is possible for the agriculture sector to lose more workers as they would migrate to the cities for employment.

\section{CONCLUSION}

To conclude, the establishment of AEC will bring challenges and opportunities. So, Myanmar needs to make use of the opportunities and prepare for the challenges. To take advantage of AEC, both the farmers and the government need to work together. Following are some recommendations to both the farmers and the government officials.

Firstly, it is very important for the farmers to be knowledgeable about agriculture, marketing and AEC. Thus the government should give public information about AEC, GAP standards and food security. Likewise, they should provide more frequently training about agricultural processes like production, marketing, technology, management, and economics. As for the farmers, they should give attention to what the government is teaching, saying and doing. They need to be open to learn new things that the government officials are teaching and mature attitude. When they learn new things, they need to do it practically instead of relying only on the government.

Secondly, the government should give more support to the farmers, e.g. providing rules and regulations to protect the farmers, introducing new agriculture methods, creating a better infrastructure, providing loans, subsidies, and warehouses, preparing long-term projects and so on. At the same time, the farmers need to be patient, resilient and diligent in order to implement changes. Moreover, they need to have a long term perspective. Instead of using a short cut like using chemical fertilizer to produce quality seeds, it is better to use a sustainable way like organic material to prepare the soil and produce crops. Chemical fertilizer is easy to use and has an immediate result on the crops, but it damages the soil. Once it is used, it needs to be used more and more each time because the soil is being damaged. Organic fertilizer needs a long time to prepare the land and to see the result, but it is healthy and lasts long.

Concluding, the implementation of AEC will bring many opportunities and challenges for the farmers, it can be stated that in order to survive in the highly competitive market, it would be best for the farmers to produce the crops according to the GAP standard or get an organic certification. 


\section{REFERENCES}

Formanes, B., (2006). The Impact of AFTA on Philippines Economy and Small Scale Producers, South East Asian Council for Food Security and Fair Trade (SEACON).

Garay Salamanga, L.J., Gomez, F.B., \& Landinez, I.C., (2009). Impact of the US-Colombia FTA on The Small Farm Economy in Colombia, Oxfam International.

Hidayat, A.R., \& Regalado, A.A., (2006). The Impact of AFTA on Indonesian Economy and Small Scale Producers, South East Asian Council for Food Security and Fair Trade (SEACON).

Htoo Thit, (2013). Agriculture: facing the problem of insufficient labors, Agricultural Technology and grazing land Specialization, The Farmers, 151-155.

Jr., P.S., S. Oum, and M. J. O. Simorangkir (eds.), Agricultural Development, Trade and Regional cooperation in Developing East Asia, Jakarta: ERIA, pp.625-669.

Key Indicator for Asia and the Pacific 2014. Asian Development Bank (ADB).

Myanmar Agriculture in Brief. (2011). Department of Agricultural Planning, Ministry of Agriculture and Irrigation.

Nin-Pratt, A., Diao, X., \& Bahta, Y., (2008). Assessing Potential Impacts on Agriculture of a Regional Free Trade
Agreement in Southern Africa, Regional Strategic Analysis and Knowledge Support System (ReSAKSS) Working Paper No.15.

Rasiah. R., Al-Amin. A. Q., \& T.H. Naing (2011), 'Integrating Myanmar with its Western and Northern Neighbors: A Shared Vision through the promotion of Sustainable Agricultural Development' in Inta'l,

Thanh Loc, V., T., (2001). The AFTA Impact on Vietnam's Economy. CAS Discussion Paper No. 35.

The ASEAN Secretariat, (2006). ASEAN GAP: Good Agriculture Practice for production of Fresh Fruit and Vegetable in ASEAN.

The ASEAN Secretariat, (2008). The ASEAN Economic Community Blueprint.

Umezaki, S., (2012). Building ASEAN Economic Community: Challenges and Opportunities for Myanmar, In Economic Reforms in Myanmar: Pathways and Prospects, BRC Research Report No.10, Bangkok Research Center, IDEJETRO, Bangkok, Thailand

Win Shwe, M.T. (2013). Towards Agricultural Development; From Resource Based to Technology Based. Agricultural Technology and grazing land Specialization, The Farmers, 98-101.

$--0--$

Publish Online and Print Version Both

Online Archive: $\underline{h t t p}$ ://journals.abc.us.org/index.php/abr/issue/archive

Indexed Archive Links

OCLC WorldCat: http://goo.gl/vhQzla

Google Scholar: https://goo.gl/t23FeQ

abcGATE: http://goo.gl/E6WdgA

BASE: http://goo.gl/sEd0SZ

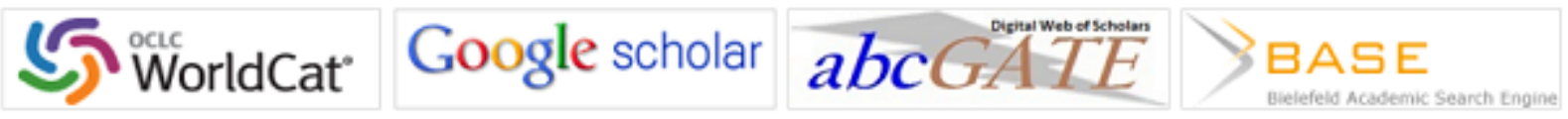

